\title{
Forehand Drive Exercise Model in Table Tennis Game
}

\author{
Bessy Sitorus Pane \\ Pendidikan Jasmani \\ Universitas Negeri Jakarta \\ Jakarta, Indonesia \\ bessysitorus_por16s3@mahasiswa.unj.ac.id
}

\author{
James Tangkudung \\ Pendidikan Jasmani \\ Universitas Negeri Jakarta \\ Jakarta, Indonesia \\ james24061952@gmail.com
}

\author{
Abdul Sukur \\ Pendidikan Jasmani \\ Universitas Negeri Jakarta \\ Jakarta, Indonesia \\ abdulsukur69@yahoo.com
}

\begin{abstract}
Forehand drive is a way of making a shot which the ball must be hit using the palm of the hand holding the bet facing forward. It requires exercise to be executed properly. Thus, the purpose of study was to develop forehand drive exercise model in table tennis game. The method used Research and Development (R\&D) from Borg and Gall which consists of ten stages. The participants ware beginner athlete at PTM Gajah Mada Medan who participate in field test. Data were collected through documentation, observation, interview and test of forehand drive in table tennis. Data analysis used qualitative and quantitative data and the study provided judgment expert. The results study concluded that there are 21 of exercise model for forehand drive in table tennis game. It gave the beginner athletes high enthusiasm for forehand drive practice. The implication of study shows that there are variations in practice of hitting ball in table tennis game and it had an impact on the level of interest of beginner athletes in table tennis learning
\end{abstract} Game

Keywords-Exercise Model, Forehand Drive, Table Tennis,

\section{INTRODUCTION}

The table tennis has a variety of basic techniques, namely grips, stances, footwork and strokes. Mastery of technique helps players to defend and block the ball. When striking, punching techniques and leg movements must be ready. For beginner athletes, these techniques must be trained, especially hitting techniques. Hitting is one of the most important techniques in table tennis. When they do not have hitting skills, players will lose points in a match. It makes table tennis coaches prioritize their athletes to practice hitting skills rather than other skills. In order for hitting skills to be mastered properly, it takes a long time for practice and various exercise models. Athletes do not only hit the ball, but the athlete must hit the ball with the palms of the hands holding the racket facing forward. This is called a forehand drive.

There are several components in making a forehand drive that must be considered based on the experience of the PTM Gajah Mada coach, namely being able to hit back the opponent's ball and direct the ball to an area that is difficult for the opponent to reach. In addition, the hitting stage must be able to position all parts of the body using the existing basic hitting techniques because in table tennis, hitting technique is a basic technique that is first taught to beginner players and this technique is quite an important technique.

The results of observations and interviews with athletes or coaches at PTM Gajah Mada found several facts about the problem of forehand drive activity in table tennis. Beginner athletes still have difficulty mastering basic forehand drive techniques such as late hitting a bouncing ball, unbalanced racket swing with the arrival of the ball, monotonous exercise models and lack development of other forehand drive exercise models. The game of table tennis becomes less interesting and seems ordinary. Even though the game of table tennis is not only about sports, but playing with fun. This can be done if the mastery of the forehand drive is good enough.

Many previous studies have concluded that the forehand drive has a very important role in table tennis. [1] The right training method can provide coordination to the athlete's hand with the right to hit the ball.[2] To find out the ability of forehand drive, you can use a test, such as the table tennis athlete of Semen Padang who is given a test to measure the ability of the forehand drive.[3] In addition, to produce forehand accuracy, one should try to apply a form of exercise using two tables.[4] Multiball practice can also be used to improve your forehand drive skills[5][6] and backhand skills in table tennis.[7] It is more effective to teach forehand drive.[8][9] Even the multiball training method was more significant in the frequency of the table tennis than the shadow training method.[10] In addition, the drill training method can improve students' groundstroke abilities.[11] The forehand training model can also take advantage of various media, such as films[12]

In Pane research, et al. have developed the forehand drive training concept into 4 main parts, namely shadow ball, rolling ball, multiball MP and multiball DP.[13] Each type of exercise has 3 levels, namely difficult, medium, and easy with each training development at each level, there are 2 types. Therefore, this study develops the four components with a variety of exercise models according to the needs of beginner athletes. This research is important to do for several reasons, namely (1) a variety of exercise models can provide motivation for athletes to learn forehand drive, (2) athletes view the ball to be more focused, (3) the right exercise model can provide an increase in hand-drawn movement backward when the ball comes, 3) the exercise model can provide a balanced waist rotation speed with the backward pulling motion when the ball reaches the hit area, (4) various training models can provide training for good standing positions, and 
(5) various exercises can build player concentration because this type of table tennis game becomes fun.

The development of various forehand drive exercise models makes a difference to previous studies because the forehand drive exercise model in this table tennis game has a development mechanism so that it can make the training of PTM Gajah Mada Medan for beginner athletes is effective. This exercise model emphasizes the role of the environment as the main source of exercise model development. Therefore, the aim of this study is to develop a variety of exercise models for forehand drive in table tennis. This research is expected to contribute for the development of a forehand drive which is considered difficult for beginner athletes, especially at PTM Gajah Mada Medan. So, the formulation of the problem in this study is "how does the forehand drive exercise model in table tennis?"

\section{METHOD}

\section{A. Research Method}

This study used research and development method through Borg and Gall model.[14] It has 10 steps to develop the forehand drive exercise in table tennis game. This method used to fulfill the sport needs in table tennis game and it produced the model of forehand drive exercises for beginner athlete at PTM Gajah Mada Medan. Therefore, this study used qualitative and quantitative data because it is mixed method[15]

\section{B. Procedure of Research}

The initial step is to collect data for needs analysis of the forehand drive exercise model in table tennis for beginner athletes and analyzes the theory. The second step is to analyze the data obtained from observations, interviews, and questionnaires. The data that has been analyzed is used to design a table tennis forehand drive exercise model. The third step is to validate the initial model design through expert judgment. After the researcher received advice from experts, the model design was improved so that it could be used for small group testing. Limited product trials by practicing the training model at PTM or clubs. Participants who do table tennis exercises with various forehand drive exercise models will provide advice. The input data is used as data to improve the forehand drive training model. After the researchers made improvements, the model was tried again with a larger number of participants. The final step is to improve the final model so that the researcher gets the final product.

\section{Technique of Data Collection}

Process of data collecting data used observation, interview, and questionnaire. Observation was done through Observations were done through direct observation to the PTM or table tennis club to find out the types of exercises commonly used by beginner players. Interviews were conducted with beginner players to find out their opinion regarding the types of forehand drive exercises that suit their needs. After that, the researcher gave a questionnaire related to the forehand drive exercise model in table tennis.

\section{Analysis Data}

Process analysis data used trial of filed in small group and large group, peer assessment, and judgment expert.

\section{FINDING AND DISCUSSION}

The result of needs analysis data concluded that the forehand drive exercise model in table tennis which is applied in PTM Gajah Mada is less varied and monotonous so that athletes are less motivated in carrying out the exercises. The players also do not have a specific training schedule. Forehand drive exercises are performed only at certain times. While training also only uses racks and balls. While exercises equipped with media can generate different enthusiasm from athletes. As has been done by Royana, et al. have developed a roll spin training media for forehand spin training in table tennis[16] and visual effect will help the player in tennis table playing easier.[17]

The results of the questionnaire analysis distributed to 20 athletes concluded that $20 \%$ of athletes knew about the forehand drive technique exercise model, $100 \%$ of athletes felt boring in forehand drive technique exercise, $15 \%$ of coaches had used various forehand drive exercise models, $15 \%$ of the time for technical exercise forehand drive is sufficient, $100 \%$ of athletes agree that if they are given forehand drive technique exercise, $100 \%$ of coaches must provide varied exercise to forehand drive technique, $100 \%$ of athletes agree that forehand drive technique exercise requires a variety of exercises, $100 \%$ of coaches agree if development is carried out forehand drive technique training model for athletes, $100 \%$ of athletes agree that a variety of training models will improve forehand drive ability. Thus, the exercise model in forehand drive activity needs for beginner athlete.

Therefore, the results of judgment expert and small group tests of the forehand drive training model can be seen in the table below.

Table 1. Exercises Model of Forehand Drive

\begin{tabular}{llll}
\hline & Exercise Model & Score & Conclusion \\
\hline 1 & Drive Basic & $88 \%$ & Valid \\
2 & Drive two & $75 \%$ & Quite Valid \\
3 & Wonder Wall & $83,3 \%$ & Valid \\
4 & Iron Hand & $80 \%$ & Valid \\
5 & Hit the Table & $58,3 \%$ & Less Valid \\
6 & Swing the Hip & $83 \%$ & Valid \\
7 & Strike Zone & $94 \%$ & Valid \\
8 & Strike Time & $91,7 \%$ & Valid \\
9 & Counter Strike & $58 \%$ & Less Valid \\
10 & Strong Hand & $77 \%$ & Quite Valid \\
11 & Hit and Move & $88 \%$ & Valid \\
12 & Drag the Ball & $75 \%$ & Quite Valid \\
13 & Hit and Hit & $86,11 \%$ & Valid \\
14 & Head to Head & $80 \%$ & Valid \\
15 & Shift and Balance & $80 \%$ & Valid \\
16 & Moving Nice & $88 \%$ & Valid \\
17 & Speed and Balance & $75 \%$ & Quite valid \\
18 & Strike Zone & $83,3 \%$ & Valid \\
19 & Constant Motion & $80 \%$ & Valid \\
20 & Step and Hits & $80 \%$ & Valid \\
21 & Hit and Hit & $83 \%$ & Valid \\
22 & Step by step & $88 \%$ & Valid \\
23 & Multi Hit & $91 \%$ & Valid \\
24 & Precision Ball & $55 \%$ & Less valid \\
\hline
\end{tabular}


Based on the result of a small group trial of 10 beginner athletes, it was found that $73 \%$ the beginner athletes had completed the forehand drive correctly. Meanwhile, large group trial activities were carried out on 30 beginner athletes were $100 \%$. In a large group trial, the ethletes showed good enthuasiasm and were able to understand the flow of the forehand drive technique so it was very easy to implement. The results of the large group trial showed that completeness of the exercises for forehand drive had reached $84.5 \%$. It means that the research is sufficient to determine its validity because some of the deficiencies in the small group test have been revised by researchers. The average result of the test before being given the forehand drive exercise model is 7.35 and the average test result after being given the forehand drive exercise model is 10.15 , there is an increase resulting from the pre-test to the post-test. Thus it can be concluded that the implementation of the forehand drive exercise model in table tennis has a significant effect on the strokes used by beginner athletes. Each exercise method is related to one another that support the success of forehand drive training. [18] It is able to icrease the forehand drive ability.[19] The coach has to provide the motor skill in training.[20]

The results of assessments from experts, peers, and athletes, it is known that of the 24 exercise models tested, there are 3 invalid exercise models, namely hit the table, counter strike, and precision ball. While there are 4 valid exercise models, namely drive two, strong hand, speed and balance, and drag ball. The four exercise models are considered usable, but this exercise model has a non-dominant effect on forehand drive mastery. So, there are 17 exercise models that are considered valid and in accordance with the needs of beginner athletes in the forehand drive activity for table tennis. The forehand drive exercise model has been refined according to input from experts on several components, including 1) detailed instructions and implementation of the forehand drive movement, 2) The illustration of the forehand drive exercise model is designed according to the needs of the athlete, and 3) the movements in the training start from the basis which is performed repeatedly and combined with other stroke movements, and 4) the exercise model has been designed with a level of safety from possible injuries that arise.

The forehand drive exercise model product that has been developed has several advantages;

1. Forehand drive is easy to do for beginner athlete.

2. Exercise model gave the variation in forehand drive training.

3. The beginner athlete has high motivation in tennis table game.

4. The exercise model of forehand drive is appropriate to improve forehand drive ability because it were more effective and efficient.

5. This model is a main references in forehand drive training.

6. This model has been designed in order of difficulty level While some of the limitations found are:
1. The study has less media in implementing of exercise model of forehand drive.

2. Athletes' motivation influence the training activity.

3. The forehand drive training activity management system still has drawbacks when it applied to athletes who have less motivation.

\section{CONCLUSION}

The forehand drive exercise model in table tennis has a variety to suit the needs of beginner athletes and the atmosphere of a table tennis training environment. From the design of 24 exercise models, there are 17 valid and feasible exercise models used for forehand drive activities in table tennis. These exercise models have gone through a procedural development stage. The exercise model in forehand drive is a process of repetition of physical activity or work properly and correctly to increase the performance achievement in playing table tennis. Forehand drive exercises are carried out in a complex systematic manner to improve the quality of athlete's performance in playing table tennis in the form of physical fitness, skills, and energy capacity. The forehand drive exercise model in table tennis has the aim of improving table tennis learning. The forehand drive exercise model is also designed to be repeated repeatedly so that beginner athletes can do their existing skills to do a better forehand drive.

The results of this study also have implications for the availability of a forehand drive exercise model in table tennis which varies according to the abilities and needs of the athletes. It has made learning table tennis for beginner athletes more interesting and fun. In addition, every athlete has a high enough enthusiasm level to train on a scheduled basis. However, during the research process it was found that the researcher had faced difficulties, namely in terms of providing the media used to develop exercise models. Thus, for the next research, forehand drive exercise models can be developed which are equipped with various media such as visual or audio.

\section{ACKNOWLEDGMENT}

Thank you are conveyed to the beginner athletes at PTM Gajah Mada Medan, trainers and administrators from PTM Gajah Mada and all those who have helped during the data collection process until the trials.

\section{REFERENCES}

[1] J. T. Susetyorini, T. Rahayu, and S. Rahayu, "Effect of Exercise Methods and Eye-Hand Coordination on Forehand Drive Table Tennis Basic Technical Ability," J. Phys. Educ. Sport., vol. 8, no. 3, May 2019.

[2] N. Asri, S. \& Siti, B. Mukarromah, and S. Artikel, "Journal of Physical Education and Sports Pengaruh Metode Latihan Multiball dan Koordinasi Mata Tangan terhadap Peningkatan Keterampilan Forehand Drive Tenis Meja Info Artikel," Sep. 2017.

[3] D. N. Sari and D. Antoni, "Analisis kemampuan forehand drive atlet tenis meja," Edu Sport. Indones. J. Phys. Educ., vol. 1, no. 1, pp. 60-65, Aug. 2020.

[4] melya herliana and melya nur Herliana, "Pengaruh Bentuk Latihan Menggunakan Dua Meja Terhadap Ketepatan Forehand Dalam Permainan Tenis Meja," J. S.P.O.R.T, vol. 3, no. 2, pp. 93-97, Dec. 
2019.

[5] A. Kurniadi, N. Saymsuddin, and A. Razak, "PENGARUH LATIHAN MULTIBALL TERHADAP KEMAMPUAN KETEPATAN PUKULAN FORHAND DRIVE CLUB PTMSI SOPPENG," Aug. 2020

[6] B. S. Waluya, K. Tahki, and I. Setiawan, "Pengaruh Latihan Multiball dan Berpasangan Terhadap Ketepatan Forehand Drive Pada Ekstrakurikuler Tenis Meja di Sekolah SMP Negeri 14 Jakarta," J. Pendidik. Jasm. dan Adapt., vol. 2, no. 1, 2019.

[7] M. QOID FALAHI and D. ANDRIJANTO, "PENGARUH METODE LATIHAN MULLTIBALL TERHADAP KETERAMPILAN PUKULAN DRIVE PADA EKSTRAKURIKULER TENIS MEJA," J. Pendidik. Olahraga dan Kesehat., vol. 7, no. 3, 2019.

[8] A. Sukamto, "Comparison of Training Methods and Motoric Skills to Exercise Results of Drive ShotTechnique at Table Tennis," Int. J. Sci. Eng. Dev. Res., vol. 2, no. 10, pp. 39-41, 2017.

[9] S. Nurdianti, D. MUDIAN, and A. RISYANTO, "PENGARUH METODE LATIHAN MULTIBALL DAN LATIHAN DENGAN PEMAIN LAIN TERHADAP KETEPATAN FOREHAND DRIVE PADA SISWA EKSTRAKULIKULER TENIS MEJA SMA NEGERI 1 JALANCAGAK TAHUN 2018," Biormatika J. Ilm. Fak. Kegur. dan ilmu Pendidik., vol. 4, no. 02, pp. 25-37, Oct. 2018.

[10] E. Setyawan, I. Safari, and Y. Akin, "PERBANDINGAN LATIHAN SHADOW DENGAN LATIHAN MULTIBALL TERHADAP FREKUENSI PUKULAN FOREHAND DRIVE TENIS MEJA," SpoRTIVE, vol. 1, no. 1, pp. 241-250, 2018.

[11] M. Latihan Drill Berpengaruh Terhadap Kemampuan Groundstroke Tenis Lapangan Hendri Irawadi, M. Jaqfaruhdin Yusuf, H. Irawadi, and P. Jalan Hamka Air Tawar Barat, "Metode Latihan Drill Berpengaruh Terhadap KemampuanGroundstroke Tenis Lapangan," Dec. 2019.

[12] A. G. Dehkordi, "The effect of instructional-aid films on learning of table tennis techniques," Procedia - Soc. Behav. Sci., vol. 15, pp. 1656-1660, Jan. 2011

[13] B. S. Pane, J. Tangkudung, and A. Sukur, "Drill Based Model of Forehand Drive Practice in Table Tennis for Beginner Athlete," $J$. Phys. Educ. Sport. Heal. Recreat., vol. 9, no. 1, pp. 48-52, 2020.

[14] L. . Gay, E. M. Geoffrey, and P. Airasian, Educational Research Competencies for Analysis and Applications Ninth edition. United State of America: Pearson, 2012.

[15] J. W. Creswell, Research, Educational Planning, Conducting, and Evaluating Quantitative and Qualitative Research, 4th ed. Boston, 2012.

[16] I. F. Royana, U. H. Zhannisa, and T. Herlambang, "Roll spin: forehand spin training media in table tennis," J. Sport. J. Penelit. Pembelajaran, vol. 5, no. 1, p. 113, May 2019.

[17] F. Basiri, A. Farsi, B. Abdoli, and M. Kavyani, "The Effect of Visual and Tennis Training on Perceptual-Motor Skill and Learning of Forehand Drive in Table Tennis Players," J. Mod. Rehabil., vol. 14 , no. $1,2020$.

[18] A. Wiguna, S. Surisman, and A. Jubaedi, "PERBANDINGAN METODE BAGIAN DENGAN METODE KESELURUHAN TERHADAP FOREHAND DRIVE TENIS MEJA," JUPE (Jurnal Penjaskesrek), vol. 4, no. 3, Apr. 2018.

[19] M. Hanim and T. Tomoliyus, "Design of Table Tennis Tool for Drive Stroke Drill Training to Beginner," in Proceedings of the International Conference of Science and Technology for the Internet of Things, 2019.

[20] S. J. Douvis, "Variable practice in learning the forehand drive in tennis.," Percept. Mot. Skills, vol. 101, no. 2, pp. 531-45, Oct. 2005. 